\title{
The Legal Boundaries of 'Public Purpose' in India and South Africa: A Comparative Assessment in Light of the Voluntary Guidelines
}

\author{
Björn Hoops *(1) and Nicholas K. Tagliarino \\ Faculty of Law, University of Groningen, P.O. Box 72, 9700 AB Groningen, The Netherlands \\ * Correspondence: b.hoops@rug.nl
}

Received: 16 September 2019; Accepted: 15 October 2019; Published: 17 October 2019

\begin{abstract}
The Voluntary Guidelines on the Responsible Governance of Tenure (VGGT) call for governments to clearly define the term 'public purpose' to allow for judicial review of the goals of expropriations of property. However, recent research indicates that national-level legal frameworks that govern expropriation decision-making not only vary greatly from country to country but also often fail to comply with the VGGT standards on expropriation. This creates the potential for unpredictable and, in some cases, arbitrary applications of expropriation law in practice. Focusing on legal norms and jurisprudence applicable to 'public purpose' decision-making in South Africa and India, this article provides a comparative analysis of these countries' legal frameworks as means of ascertaining (1) the current legal boundaries to decisions on the expropriation's goal; (2) whether these boundaries comply with the VGGTs; and (3) what these two countries can learn from one another in terms enacting legislation and regulations that comply with the VGGTs. To conduct this comparative analysis, we thoroughly examine constitutional provisions, relevant case law, legislation, regulations, and relevant secondary sources to highlight the current status of India's and South Africa's law on 'public purpose' and how they relate to the VGGTs. We conclude by distilling some key findings that can inform the decisions of expropriation lawmakers in both countries, especially in South Africa where a draft Expropriation Bill is currently being considered.
\end{abstract}

Keywords: expropriation; public purpose; land acquisition; judicial review

\section{Introduction}

The law limits the goals for which governments may acquire property against the owner's will in order to use the property or transfer it to another entity (expropriation). In most jurisdictions, expropriation is only permitted if the government shows the targeted property is needed for a 'public purpose' [1]. Yet the definition of 'public purpose' and the parameters by which governments decide what constitutes a 'public purpose' vary depending on the country and context. Without clarity around the concept of 'public purpose', governments may misuse or abuse expropriation power by arbitrarily justifying an expropriation decision under the pretext of a public purpose when the actual purpose will not serve public interests. This is also because open and ambiguous definitions of public purpose limit the potential for effective judicial oversight.

In some cases, economic development expropriations that benefit from open and ambiguous definitions of 'public purpose' can be controversial even if their stated aim is to promote private business activities that create jobs and stimulate economic growth. If expropriation is permitted for such 'economic development', but laws do not establish proper limits to the government's decision-making such as checks to ensure that the project generates jobs or economic growth for local populations, then expropriation may be used as a tool for transferring land to private companies. For instance, in rural 
areas with fertile agricultural land, government authorities seeking to increase the productivity of land may decide the expropriation of smallholder farms is justified to increase agricultural production and economic growth [2]. Expropriation law in Tanzania permits the government to expropriate land whenever the President is satisfied that a corporation requires any land for 'agricultural, commercial, and industrial development' or for construction of any work that in the President's opinion would be of public utility; as a result, expropriated rural land has routinely been transferred to private actors [3]. A World Bank study indicates that expropriations were often perceived by the public as aiming to push out poor and indigenous landowners to allow the rich or the state to derive major benefits [4]. Likewise, in Nigeria, World Bank research indicates local landholders commonly view expropriation as a tool for "dispossessing the poor to elevate the rich" [5]. Similarly, in Rwanda, one study indicated that expropriations have been on the rise since 2012, with many affected households expressing dissatisfaction [6].

Limits to Government decision-making and the definition of 'public purpose' are essential to the legitimacy of the expropriation and the implemented project. Discontent with transfers of expropriated property to private companies for economic development purposes may find its expression in lawsuits, such as the Kelo case before the United States Supreme Court [7]. In a range of countries, the debate around what constitutes a legitimate 'public purpose' has even spiraled into conflict. In China, for example, affected landholders organized a protest in the early 2000s, which lasted for several years after government officials seized farmland that had been under village control since imperial times [8]. The government expropriated the landholders' farmland for the purpose of real estate development. In response to the sit-in, Chinese police reportedly sprayed tear gas and fired rubber bullets at the protesters [9].

To promote proper legal limits to the power of Governments to expropriate property and to prevent such conflicts, the Voluntary Guidelines on the Responsible Governance of Tenure (VGGT) contain guidelines on expropriation, compensation, and resettlement. Guideline 16.1 specifically concerns the goal of expropriation and recommends that only public purposes should justify expropriations and that the State should specify the notion of 'public purpose' in law to enable the judiciary to review the goal of expropriation. This safeguard against expropriations for illegitimate purposes is particularly important in the context of expropriation for economic development because there is no natural limit to the number of private business projects and such projects create incentives for authorities to collude with project developers [10].

To make sure that national laws impose the limits recommended in the VGGT, national laws need to be assessed in the light of the VGGT. This contribution compares and assesses Indian and South African law. A comparison of these two jurisdictions is appropriate because both of these countries inherited English administrative and expropriation law as former British colonies. India and South Africa are also both emerging economies with similar administrative and economic challenges. This makes it more likely that their laws are adjusted to the capacity of their administrative system and that they can fruitfully adopt each other's instruments. A comparison is also timely because of the recent reform of India's expropriation law and the debate over new expropriation legislation in South Africa.

An assessment of the South African and Indian legal systems, specifically in respect of the issue of 'public purpose', is worthwhile because in both India and South Africa, the debate around 'public purpose' has historically been a contested issue, with a wave of heated protests and public debate apparently increasing in recent years [11]. In South Africa, specifically, there has been significant public debate over whether expropriations are justified for the purpose of redistributing land from the historically privileged white minority to the historically disadvantaged black majority [12]. On 27 February 2018, the National Assembly set in motion a process to amend the Constitution to allow for the expropriation of certain properties without compensation. The process is influenced by the Economic Freedom Fighters political party to address the unequal distribution of land caused by colonialism and Apartheid. Legitimate as this cause may be, the option to resort to expropriation 
without compensation may fuel the abuse of state power in a legal order that provides an extremely broad authorisation to expropriate property and also lacks other safeguards laid down in international good governance standards [13]. The draft 2019 Expropriation Bill, which is currently being considered in South Africa, only partially alleviates this concern because it provides for rather broad boundaries to expropriation without compensation [14].

Land expropriation in India has historically been a pervasive and contentious issue with a significant amount of protest and challenges in court from affected landholders, including poor farmers, Scheduled Tribes and Castes (officially designated as historically disadvantaged people in India), and other vulnerable groups displaced by expropriation. For example, in response to an expropriation in 2011, farmers vehemently protested a government decision to expropriate village land in 2011, arguing the expropriation for an industrial development plan was unjustified because it did not serve a public benefit [15]. The Supreme Court of India ultimately ruled the expropriation illegal, on the grounds that in the name of the public interest, the Greater Noida Industrial Development Authority was serving private interests [16].

Expropriation cases focused on the legitimacy of the public purpose are not uncommon in India. One recent study examined all expropriation cases decided by the Supreme Court between 1950 and 2016 found that one third of all cases involved claims by affected landholders who questioned the legitimacy of the land acquisition process or the purpose for which the land was acquired; many of these landholders refused to give up their land [17]. The long history of expropriation and forced displaced galvanized a large population of rural farmers and other marginalized groups to demand legal reform in India [18].

In 2013, India enacted the Right to Fair Compensation and Transparency in Land Acquisition, Rehabilitation and Resettlement Act, 2013 (LARR Act) [19]. The LARR Act replaces the colonial-era Land Acquisition Act 1894, a law that, according to the Minister of Rural Development, "was draconian" and contributed to landholder impoverishment [20]. Lindsay et al. highlight how the LARR Act was adopted against a backdrop of increasingly vociferous public protest about large land acquisitions on behalf of private industries that were supported at least in part by expansive legal interpretations of the public use/purpose doctrine [21].

In the light of the VGGT and other international guidance on 'public purpose', this article deals with the purposes that can justify an expropriation and the bodies that determine which goals can justify an expropriation in India and South Africa, and whether these countries' laws comply with internationally recognized standards on expropriation. This contribution employs doctrinal legal methods in that it analyses primary and secondary legislation as well as case law to determine what the law is in India and South Africa. Moreover, it employs the functional method of comparative law to compare the law of these two jurisdictions [22]. This method requires the identification of a shared issue and an analysis and comparison of the law of each jurisdiction insofar as it addresses this issue. The goals that can justify an expropriation in India and South Africa serve as this shared issue and are referred to as 'public purposes' in this contribution. The analysis focuses on expropriations for economic development, a legal grey area in many jurisdictions. The analysis suggests steps for South Africa and other countries to follow if they aim to pass laws that comply with international standards.

This article is organized as follows. First, we highlight the relevant international standards established by the VGGT. Second, we examine the issue of 'public purpose' as it has been handled by Indian legislation and jurisprudence, providing a comparative analysis that measures India's legal framework against the VGGT. Third, we examine the public purpose/public interest requirement in South Africa in the light of the relevant Voluntary Guidelines. Finally, we conclude by providing a set of recommendations on legal reforms that should be incorporated into the final version of South Africa's 2019 expropriation bill to ensure compliance with the VGGT standards on 'public purpose'. 


\section{International Standards on Public Purpose}

In the past few years, various organisations have adopted international instruments on good governance of land tenure [23]. The instrument with the most general scope of applicability is the Voluntary Guidelines. The Committee on World Food Security (CFS), which has 193 member countries, officially adopted the VGGT in 2012 after a thorough bottom-up consultation process in which stakeholders from all over the world participated [24]. Guideline 16 is dedicated to expropriation, compensation, and resettlement.

Concerning the public purpose requirement, Guideline 16.1 of the Voluntary Guidelines recommends that:

"States should expropriate only where rights to land, fisheries or forests are required for a public purpose. States should clearly define the concept of public purpose in law, in order to allow for judicial review."

The Voluntary Guidelines thus recommend that states only expropriate property for public purposes. The Guidelines, however, do not give a substantive definition of public purposes. What Guideline 16.1 does is that it assigns to the states the task to define the concept of public purpose in law. While in civil law jurisdictions, such as jurisdictions in continental Europe, it is for the legislature to lay down the concept of 'public purpose' in law, common law and mixed jurisdictions, such as India and South Africa, it may be either for the courts or the legislature to do so [25].

Guideline 16.1 further specifies that is the function of the public purpose requirement to prevent expropriations for illegitimate purposes. According to the Guidelines, the courts should ensure that the public purpose requirement can perform this function. This entails that the definition of the public purposes in law must be such as to enable judges to effectively review whether the public purpose requirement has been met.

While the VGGTs do not define what should constitute a 'public purpose' for a legitimate expropriation of land, there are other internationally recognized guidance documents that provide some clarity on this term. The Food and Agricultural Organization of the United Nations (FAO) developed a guidance document in 2008, which calls for governments to provide clearly defined lists of public purposes in legislation provide an established inventory of permissible purposes beyond which the government may not expropriate land [26]. Such an inventory provides criteria that people can use to challenge proposed justification decisions in court. Laws with clear lists of public purposes (e.g., public infrastructure projects, national defense) provide courts with better guidance when ruling on expropriation cases and diminish the potential for conflicting court decisions. The FAO guidance document provides a list of commonly accepted public purposes based on a broad survey of developed and developing countries:

- Transportation uses including roads, canals, highways, railways, bridges, wharves, and airports

- Public buildings including schools, libraries, hospitals, factories, religious institutions, and public housing

- Public utilities for water, sewage, electricity, gas, communication, irrigation and drainage, dams, and reservoirs

- Public parks, playgrounds, gardens, sports facilities, and cemeteries

- National defense purposes

While these international standards and guidance documents provide some clarity regarding how legal frameworks should deal with the issue of public purpose, many countries have not established laws that comply with international standards in the VGGTs. The remainder of this article examines the legal frameworks of India and South Africa to determine the extent to which the legislature or the courts have defined 'public purposes' in law and whether this term's definition is designed to ensure effective judicial review of the expropriation's goal. Based on a legal comparison, this article then puts forward recommendations on how the legal systems could comply with the VGGT by learning from each other. 


\section{The Public Purpose Requirement under India's LARR Act}

Since the passage of the LARR Act in 2013, there are now more legislative restrictions on how public purpose determinations are made in India. The legislative history behind the LARR Act indicates that it was intended to only permit expropriated land transfer to private companies for uses likely to prove useful to the public [27]. In other words, the LARR Act is not intended to support private speculation.

This section is organized as follows. It first discusses the specificity of the 'public purpose' definition as established in the LARR Act. Next, it highlights additional limits on the government's authority to expropriate property, including consent and social impact assessment (SIA) requirements. This section then examines how and the extent to which judges have scrutinized 'public purpose' decision-making in India. Finally, it assesses India's legal requirements applicable to 'public purpose' in light of international standards established in the VGGT.

\subsection{The Specificity of Expropriation Legislation}

Under the LARR Act 2013, there is a clearly prescribed list of public purposes for which land can be expropriated [28]. This list includes military/national defense projects, infrastructure projects including mining, agriculture, and industrial corridor projects, housing projects, urban development projects, and residential projects [29]. Additional permissible purposes are shown in Table 1. Additionally, the LARR Act aims to diminish the misuse of the urgency clause (the provision by which land expropriation may be expedited in emergency circumstances (e.g., matters of 'national security') by limiting the invocation of the urgency clause to situations involving India's defence, national security or for emergencies due to natural calamities, and any other emergency with the approval of Parliament (LARR Act 2013, Section 40).

Table 1. Public Purpose as defined by the Land Acquisition, Rehabilitation and Resettlement (LARR) Act.

Section 2(1) of the LARR Act stipulates that "[t]he provisions of this Act relating to land acquisition, compensation, rehabilitation Act. and resettlement, shall apply, when the appropriate Government acquires land for its own use, hold and control, including for Public-sector Undertakings and for public purpose, and shall include the following purposes, namely:

(a) for strategic purposes relating to naval, military, air force, and armed forces of the Union, including central paramilitary forces or any work vital to national security or defence of India or State police, safety of the people; or

(b) for infrastructure projects, which includes the following, namely: (i) all activities or items listed in the notification of the Government of India in the Department of Economic Affairs (Infrastructure Section) number 13/6/2009-INF, dated the 27th March, 2012,excluding private hospitals, private educational institutions and private hotels; (ii) projects involving agro-processing, supply of inputs to agriculture, warehousing, cold storage facilities, marketing infrastructure for agriculture and allied activities such as dairy, fisheries, and meat processing, set up or owned by the appropriate Government or by a farmers' cooperative or by an institution set up under a statute; (iii) project for industrial corridors or mining activities, national investment and manufacturing zones, as designated in the National Manufacturing Policy; (iv) project for water harvesting and water conservation structures, sanitation; (v) project for Government administered, Government aided educational and research schemes or institutions; (vi) project for sports. heath care, tourism, transportation or space programme; (vii) any infrastructure facility as may be notified in this regard by the Central Government and after tabling of such notification in Parliament;

(c) project for project affected families;

(d) project for housing for such income groups, as may be specified from time to time by the appropriate Government;

(e) project for planned development or the improvement of village sites or any site in the urban areas or provision of land for residential purposes for the weaker sections in rural and urban areas;

(f) ld $>$ (f) project for residential purposes to the poor or land lessor to persons residing in areas affected by natural calamities, or to persons displaced or affected by reason of the implementation of any scheme undertaken by the Government, any local authority or a corporation owned or controlled by the State. 
Section 2(1) of The Right to Fair Compensation and Transparency in Land Acquisition, Rehabilitation, and Resettlement Act, 2013 provides a clear list of public purposes and limits the government's authority to expropriate land to these purposes by stating "public purposes shall include (...)." The LARR Act provides far more specificity than the equivalent provisions of the Land Acquisition Act 1894, which stipulated that land could be expropriated "whenever it appear[ed] to the [appropriate Government] that land in any locality is needed or likely to be needed for any public purpose [or for a company]." [30].

\subsubsection{Consent Requirement}

The LARR Act is viewed as a milestone because of its requirement that $70-80 \%$ of affected families must consent to the decision to expropriate property depending on the proposed project. The LARR Act does not establish consent requirements if the Government acquires land for its own use and control. However, if land is acquired for public-private partnerships, then the prior consent of at least $70 \%$ of affected families must be obtained [31]. If land is acquired for private companies, then the consent of at least $80 \%$ of affected families must be obtained [32]. When land is acquired in Scheduled Areas (i.e., areas held by historically disadvantaged populations), the Government must obtain the prior consent of the concerned Gram Sabha or the Panchayats or autonomous district councils [33]. The procedures for gathering consent are detailed in implementing regulations [34].

Since LARR Act allows state governments to establish new rules for gathering consent, the law potentially leaves the door open for the Government to fulfill its consent requirements through a process that does not comprehensively survey the interests of affected communities. For example, it is unclear how consent will be gathered in cases where property is held in common; it is also unclear whether the law ensures women and other vulnerable groups will be afforded adequate rights to give consent. Even if the Government establishes a comprehensive process for obtaining consent of affected persons, further problems could arise if landowners and other affected persons are not easily identifiable. Although the Act requires the Collector to update land records, land records in most parts of the country are currently fragmented, disorganized, and, in most cases, have not been updated in decades $[35,36]$. For this reason, it may be difficult to implement the consent requirements if the process for identifying who has legitimate tenure rights (and, therefore, recognized rights to give consent) is unclear.

\subsubsection{Social Impact Assessment (SIA) Requirement}

As part of the expropriation process, the government must conduct a Social Impact Assessment (SIA) study to determine whether a proposed acquisition serves a public purpose. The SIA must also include an estimation of affected families displaced, the extent of lands likely to be acquired, whether the extent of land proposed for an acquisition is the absolute bare minimum extent needed for the project, whether land acquisition at an alternate place has been considered, and a description of the nature of the social impacts and overall costs vis-a-vis the benefits of the project [37]. Section 8 of the LARR Act requires that the LARR Authority "ensure(s) that" there is a legitimate and bona fide public purpose which necessitates the acquisition of land and that only the minimum amount of land for carrying out the project is acquired [38]. The government must hold a public hearing about the SIA study [39]. The SIA study must also be reviewed by an independent expert group consisting of social scientists, local government representatives, resettlement experts, and technical experts in the subject of the project [40]. The LARR Authority must ensure that representatives of Panchayat, Gram Sabha, Municipality or Municipal Corporation are adequately represented when carrying out the SIA; however, the law does not indicate what sufficiently constitutes "adequate representation" [41]. The SIA must be made available to persons in the affected areas as well [42]. Notably, the LARR Act provides an exception by which the SIA requirement can be avoided in cases of "urgency" [43].

The law requires the LARR Authority to hold a public hearing at the affected area as a means of ascertaining the viewpoints of affected families [39]. The hearing, survey of affected families and the 
SIA must be conducted before the government can take possession of the land. Section 11 of the LARR Act 2013 requires the government to publish a notification in the Official Gazette, in newspapers, on the government website, and in the affected areas. The notification must "contain a statement on the nature of the public purpose involved, reasons necessitating the displacement of affected persons, summary of the Social Impact Assessment and the particulars of the Administrator appointed for the purposes of rehabilitating and resettlement (...)" [44]. The Government is exempted for conducting a SIA in cases of urgency such as when land is required for the defense of India, national security, and "any other emergency with the approval of parliament" [45].

\subsubsection{Review of Expropriation Decision by an Expert Group}

After the SIA is complete, it must be evaluated by an Expert Group, consisting of social scientists, representatives of the Panchayat, Gram Sabha of municipality, rehabilitation experts, and technical experts [46]. The Expert Group then makes a recommendation after determining whether the project serves a public purpose and whether the project's potential benefits outweigh the social costs. The Expert Group's recommendation is then submitted, along with the SIA, to the LARR Authority. Since the Expert Group's recommendation, the SIA, and other relevant information related to the expropriation must be made public, the law provides an opportunity for the public to scrutinize the expropriation decision; however, the LARR Authority may choose to disregard public opinion and proceed with the expropriation regardless of public opinion or Expert Group decisions.

The Social Impact Assessment is then reviewed by an Expert Group, which takes a decision and submits to the LARR Authority; the LARR Authority must then assess whether a proposed acquisition serves a bona fide public purpose [47]. Even if the Expert Group does not recommend the project, the LARR Authority can still decide to expropriate [48]. The Act only provides that the LARR Authority considers the Expert Group's report and the SIA [48]. Although the Act requires the Government to ensure that there is a legitimate public purpose with benefits that outweigh social costs and that minimum area of land required for the project is acquired, it does not subject the Government's final decision to any oversight by an independent body [48]. Unlike the Land Acquisition Act 1894, which did not contain an effective grievance mechanism for affected persons, Section 16 of the Act establishes that affected persons can object to SIA findings. The Act also states that an "Environmental Impact Assessment (EIA) study, if any, shall be carried out simultaneously and shall not be contingent upon" the SIA's completion [49].

Section 15 grants aggrieved persons whose land is likely to be acquired to object to the public purpose justification, and states that the Collector shall hear objections and make a report to submit to the Government. The LARR Authority is charged with determining what constitutes 'public purpose' but the courts may review the 'public purpose' decisions, compensation, resettlement and other related decisions made by the LARR Authority [50].

\subsubsection{Additional Requirement Relating to Scheduled Areas and Irrigated Cropland}

The Act also prohibits the transfer of land by way of acquisition in Scheduled Areas (i.e., areas held by historically disadvantaged groups) in contravention of any law (including any order or judgment of a court which has become final) relating to land transfer, prevailing in such Schedule Areas [51]. Additionally, section 41(9) provides that:

"any alienation of tribal lands or lands belonging to members of the Scheduled Caste in disregard of the laws and regulations for the time being in force shall be treated as null and void, and in case of the acquisition of such land, the rehabilitation and resettlement benefits shall be made available to the original tribal landowners or landowners belonging to the Scheduled Castes" [52].

The LARR Act does not actually prevent acquisitions of Scheduled Areas because the law also includes, in its definition of 'affected family', 'landowner', and 'persons interested', Scheduled Tribes 
and traditional forest dwellers who were granted forest rights under the FRA 2006 [53]. Furthermore, section 42 of the Act permits the acquisition of Scheduled Areas as "a last resort" provided that the prior consent of the concerned Gram Sabha or the Panchayats or the autonomous Districts in Schedule Areas is obtained [54].

Section 10 of the Act contains a special provision to safeguard food security. It stipulates that irrigated cropland must not be acquired under this Act. The provision further states that "[s]uch land may be acquired subject to the condition that it is being done under exceptional circumstances, as a demonstrable last resort, where the acquisition of the land occurs, an equivalent area of culturable wasteland shall be developed for agricultural purposes or an amount equivalent to the value of the land acquired shall be deposited with the appropriate Government for investment in agriculture for enhancing food-security."

\subsection{The Intrusiveness of Judicial Scrutiny}

With a few notable exceptions, the Supreme Court has often historically referred to the expropriating authority's decision-making when ruling on cases where the legitimacy of the public purpose was at issue. A review of over 1269 land acquisition cases brought to the Supreme Court between 1950 and 2016, found that only 6.2\% questioned the legitimacy of the purpose for which the land was expropriated; and, in only about $1 \%$ of the total dataset of 1269 cases, the Supreme Court invalidated the acquisition on grounds of violating the requirements of public purpose. The relatively small percentage of 'public purpose' questions is in part due to the fact that many of the judgments contained no information about the purpose of the acquisition, making it difficult to discern jurisprudence that can be applied across all expropriation cases [54]. Many of these cases were challenged under the Land Acquisition Act 1894 which, as discussed above, did not define the term 'public purpose' and granted the President broad discretion to interpret what constitutes a legitimate public purpose. The highly deferential nature of rulings made under the Land Acquisition 1894 is not surprising given the Act states that land can be acquired whenever the executive authority argues it is likely needed for a public purpose. For example, in Somavanti v. State of Punjab (1962), the Court decided that the government's declaration of 'public purpose' justifying expropriation for companies would constitute 'conclusive evidence' the land in question was needed for a public purpose [55]. The Court would only intervene in cases of fraud or abuse of power.

Throughout the last few decades of the 20th century, the Court followed a 'hands-off' approach to reviewing public purpose cases, often deferring to the expropriating authority's decision regarding what constitutes a legitimate public purpose justifying the expropriation of land. In 1975, in Indrajit C. Parekh of Ahmedabad and Another vs. the State of Gujarat and Others, the Court cited the broad public powers established in the Land Acquisition Act 1894 and ruled that the public purpose requirement was satisfied even the government had only nominally contributed to the acquisition in the amount of one rupee [56]. The Court in that case stated,

"We would, however, guard ourselves against being understood to say that a token contribution by the Stair towards the cost of acquisition will be sufficient compliance with the law in each and every case. Whether such contribution meets the requirement of the law would depend upon the facts of every case. Indeed the fact that the State's contribution is nominal may well indicate in particular circumstances that the action of the Stale was a colourable exercise of power [56]."

The Supreme Court's observation in Bajirao T. Kote (Dead) By Lrs. and Another vs. State of Maharashtra and Others (1994) was particularly deferential on the issue of public purpose. In that case, the Court ruled "it is primarily for the state government to decide whether there exists public purpose or not, and it is not for the Supreme Court or the high courts to evaluate the evidence and come to its own conclusion whether or not there is public purpose" [56]. Similarly, in Sooraram Pratap Reddy vs. District Collector (2008), for example, the Supreme Court of India interpreted public purpose as including "any purpose wherein 
even a fraction of the community may be interested or by which it may be benefitted" [57]. In response to this broad interpretation, Downing wrote, "there does not seem to be any conceivable limit to what purposes will be deemed to be in the best interest of the public by the acquiring governments" [58].

In the case of Radhy Shyam vs. The State of Uttar Pradesh (2011), the Supreme Court of India took a more active approach to scrutinize the public purpose decision, and ultimately struck down the government's decision to expropriate on the grounds that this decision violated the 'public purpose' requirement. In that case, it stated,

"It must be accepted that in construing public purpose, a broad and overall view has to be taken and the focus must be on ensuring maximum benefit to the largest number of people. Any attempt by the State to acquire land by promoting a public purpose to benefit a particular group of people or to serve any particular interest at the cost of the interest of a large section of people especially of the common people defeats the very concept of public purpose [59]".

The Court further stated,

"[We] must examine these questions very carefully when little Indians lose their small property in the name of mindless acquisition at the instance of the State. If public purpose can be satisfied by not rendering common man homeless and by exploring other avenues of acquisition, the Courts, before sanctioning an acquisition, must in exercise of its power of judicial review, focus its attention on the concept of social and economic justice. While examining these questions of public importance, the Courts especially the Higher Courts, cannot afford to act as mere umpires [59]."

With this ruling, the Court gave itself a more expansive role in determining whether the public purpose requirement is satisfied; it would check for abuse of power, violations of the LARR Act 2013 and state-level legislation, and whether the purpose of the expropriation was legal requirements "has been diverted for private use" [59]. This approach differs greatly from the hands-off approach to expropriation decision-making that was followed up until the early 2000s.

Another notable exception to the hands-off approach to expropriation decision-making was the case of Kedar Nath Yadav vs. State of West Bengal \& Others case of 2016 [60]. In that case, the Supreme Court re-examined the question of what constitutes a legitimate 'public purpose' that justifies the expropriation of land [61]. Distinguishing between acquisition by the government for public purpose grounds and for the benefit of private companies, the Court stipulated "such an acquisition, if allowed to sustain, would lead to the attempt to justify any and every acquisition of land of the most vulnerable sections of the society in the name of 'public purpose' to promote socio-economic development". It held that the West Bengal Industrial Development Corporation's acquisition of land to build the Tata Motors factory did not constitute a legitimate 'public purpose', but instead benefitted a private company and thus the land had to be returned to the original owners. The Court further stated that:

"when the brunt of this 'development' is borne by the weakest sections of the society, more so, poor agricultural workers who have no means of raising a voice against the action of the mighty state government, as is the case in the instant fact situation, it is the onerous duty of the State Government to ensure that the mandatory procedure laid down ... [is] followed scrupulously" [60].

The Court ordered the government of West Bengal to survey the acquired land to determine what land should be returned and then grant reacquisition rights to the original owners accordingly. Notably, the Court has held that the government was not permitted to claw back the amount of compensation already granted to affected landholders.

The claimants in Yadav were using the land for cultivation and agro-processing industries and challenged the acquisition before the high court. While their appeals were pending, the company took possession of the land and only paid compensation to some of the affected landholders. This action 
resulted in significant protest and blockades, which ultimately forced the company to abandon the project in 2008 [62]. Finally ruling in 2016, the Supreme Court was unanimous in its opinion that the government had not followed proper expropriation processes. It held that since the government did not propose a scheme industrial development that fulfilled a public need, and thus the expropriation did not satisfy the requirement of 'public purpose' under the Land Acquisition Act 1894.

It is important to note that these cases were decided when the Land Acquisition Act 1894, the predecessor to the LARR Act, was still in effect. It remains to be seen how the Supreme Court will rule on cases involving expropriations conducted under the LARR Act. For reasons described above, the LARR Act appears to provide a clearer definition of public purpose, and a more comprehensive system of checks on the expropriation authority, and thus has the potential to ensure that judicial review is used to effectively hold the LARR Authority accountable.

\subsection{Evaluation of Indian Law in the Light of VGGT 16.1}

Recent research indicates that the LARR Act 2013 puts India far ahead of many other countries in terms of its compliance with international standards on expropriation [63]. This research concluded that only five of 50 countries establish a clear definition of public purpose to allow for judicial review [64]. In these five countries, national laws provide clearly defined lists of public purposes (e.g., public infrastructure projects). These laws also indicate that governments cannot expropriate land for a purpose not explicitly included in the list. These five countries have expropriation laws of a more recent date compared to the other 46. India's LARR Act 2013 was one of the few laws reviewed that complies with VGGT 16.1 (see text in Table 2), which requires the law to specify the concept of public purpose to enable effective judicial scrutiny of the expropriation's purpose.

Table 2. Voluntary Guidelines on the Responsible Governance of Tenure (VGGT) Principle 16.1.

Subject to their national law and legislation and in accordance with national context, States should expropriate only where rights to land, fisheries or forests are required for a public purpose. States should clearly define the concept of public purpose in law, in order to allow for judicial review. States should ensure that all actions are consistent with their national law as well as their existing obligations under national and international law, and with due regard to voluntary commitments under applicable regional and international instruments. They should respect all legitimate tenure right holders, especially vulnerable and marginalized groups, by acquiring the minimum resources necessary and promptly providing just compensation in accordance with national law.

The various provisions established in the LARR Act suggest the Act complies with VGGT 16.1. First, the Act provides a clear definition of public purpose to allow for judicial review. It establishes limits on the amount of land that can be acquired for a public purpose and includes measures that help ensure the expropriation is only used when necessary as a last resort. Furthermore, it obliges the government to identify, inform, and consult affected families regarding the purpose of the expropriation. The Act also requires the government to specify the reasons and stipulates that a public consultation process must take place as part of an SIA, which is required along with an EIA. The government is also obligated to weigh the costs and benefits of the project before expropriating the land. Lastly, the Act provides special protections for poor and vulnerable groups (Scheduled Castes and Tribes), which also indicates conformity with VGGT Principle 16.1.

\subsection{State-Level Deviation from the LARR Act and the Recent Influx of Expropriation Court Cases}

Indian states are competent to legislate in the field of 'land', however, the 'acquisition and requisitioning of property' is included on the list of concurrent competences of the Constitution [65]. Therefore, both the central and state governments have jurisdiction over the same. While state-enacted rules must comply with central laws, including the LARR Act, Article 254(2) of India's Constitution permits states to override central law as long as they obtain presidential assent. In practice, states have sometimes deviated from the LARR Act by issuing new Rules under Section 109 of the LARR Act, or enacting state level land acquisition laws pursuant to using Article 254(2) of the Constitution 
of India [66]. Through the constitutional route, states have in some cases managed to override the provisions of the central law. Due to this federal-state issue, the implementation of the LARR Act has not been consistent across India's 29 states; many states have chosen to waive certain requirements established in the LARR Act $[67,68]$. In Maharashtra, for example, only private projects must adhere to consent and SIA requirements; in Tamil Nadu, many expropriations carried out under state laws are exempted for SIA and consent requirements. Andhra Pradesh reduced the notice period for public hearings that must be conducted as part of SIA. In Jharkhand, there is no requirement to return the land to its original owners if the expropriated land remains unused for five years (a requirement established in the LARR Act) [62].

The Modi government, in 2014, also passed a temporary Ordinance at the federal level that diluted the safeguards established in the LARR Act by exempting five types of projects from having to fulfill consent and SIA requirements: national security projects, rural infrastructure including electrification, affordable housing and housing for poor people, industrial corridors, and infrastructure and social infrastructure projects. Eventually this Ordinance lapsed, but it still indicated a government attempt to reduce the regulatory burden associated with land acquisitions.

In December 2018, the Supreme Court issued notices to five states seeking their responses on a plea challenging the validity of certain amendments made by them to a central law of 2013 on land acquisition [69]. The petition claimed that amendments made several states have "adversely affected the rights of livelihood of landowners and farmers." It also alleged that the state amendment violated the constitutional rights of citizens by providing exceptions by which certain projects could avoid the obligation of following the consent provisions, social impact assessment, and participation of representative local bodies in the acquisition of land. Challenges related to the compensation requirements and when will the land acquisition process shall be deemed to have 'lapsed' if not completed within a certain timeframe [70].

In 2019, the Madras High Court ruled that all land acquisitions by Tamil Nadu state after September 2013 under state laws were illegal and the land must be returned—unless already in use-as the laws bypassed the federal land acquisition law [71].

The influx of expropriation cases indicates that there needs to be more clarity around the procedures that must be followed, and the extent to which the LARR Act applies to states in India. Hopefully, a forthcoming Supreme Court ruling will provide this clarity, ensuring more consistency in the application of the public purpose requirements and procedures designed to protect landholders against abuse of power and land taking for exclusive private benefit.

\section{The Public Purpose/Public Interest Requirement in South African Law}

Section 25(2) of the South African Constitution of 1996 only permits an expropriation for a public purpose or in the public interest and based on laws of general application [72]. Section 2(1) of the Expropriation Act [73] empowers the Minister of Public Works to expropriate property for public purposes. The first part of the following analysis discusses the definition of 'public purpose' and 'public interest' in South African law. The second part then analyses the extent to which the legislature and the courts define 'public purpose' and 'public interest', and the remaining discretion of the competent authority to define the expropriation's purpose. The third part evaluates whether South African law complies with VGGT 16.1.

\subsection{The Definition of 'Public Purpose' and 'Public Interest'}

In the pre-constitutional era, under the Apartheid regime, until the Interim Constitution entered into force in 1993, expropriation was only possible for a 'public purpose'. The courts defined 'public purposes' as all purposes that pertain to and benefit the public (in contradistinction to private individuals) [74]. This definition is very abstract and appears to cover an endless variety of purposes. Accordingly, the courts approved expropriations for the security and privacy of the Prime Minister, urban development, the maintenance of the national telecommunication system, the preservation of 
vegetation, and the maintenance of water quality [75]. A project even served a public purpose if it only indirectly contributed to these purposes, for instance through the provision of housing for technicians who would then maintain the telecommunication system [76]. In the famous Van Streepen judgment, Smalberger JA held that also the 'public interest' could justify an expropriation and found that while it did not serve a public purpose, even the private supply of strategically important products served a public interest that could justify an expropriation [77]. Only projects that solely benefited private individuals could not justify an expropriation.

With the constitutional era came new uncertainties. The definition of the newly introduced 'public interest' remains unclear; Section 25(4)(a) of the Constitution only clarifies that property may be expropriated for land reform purposes. What seems settled is that 'public purpose' is a narrower category that in its entirety forms part of the greater category 'public interest', and that the drafters of the Constitution intended to provide a broad constitutional authorisation for expropriation [78]. The Constitutional Court has yet to provide clarity on the meaning of 'public purpose' and 'public interest'. To shed light on the meaning of these terms this sub-section analyses the applicable jurisprudence of the High Court and the Supreme Court of Appeal. As both public purposes and the public interest can justify an expropriation, this contribution does not deal with the distinction between these two terms any further [79].

The analysis shows that the courts have adopted the abstract definition of 'public purpose' from the pre-constitutional era and construe 'public purpose' and 'public interest' very broadly. Even indirect economic benefits of private business projects may validly justify an expropriation. In eThekwini Municipality $v$ Sotirios Spetsiotis, [80] the KwaZulu-Natal High Court decided that an upgrade of the Durban beachfront for the 2010 soccer World Cup constituted a public purpose [81]. Urban development for a global sports event is thus a public purpose. While the upgrade could still directly benefit the public through the improvement of private infrastructure, Bartsch Consult (Pty) Limited $v$ Mayoral Committee of the Maluti-A-Phofung Municipality concerned the construction of a private shopping complex [82]. Ebrahim J considered for the Free State High Court that it was the responsibility of the municipalities to ensure their economic viability and prevent rising unemployment and poverty [83]. He found that the shopping complex would provide strategic economic advantages to the municipality in the form of greater financial returns, which would then result in a healthier and wealthier environment [84]. Therefore, Ebrahim J held the shopping complex to be in the public interest.

The Supreme Court of Appeal has confirmed this broad interpretation of 'public purpose' and 'public interest' in the Offit case. A private company, Coega Development Corporation (Proprietary) Limited, indirectly controlled by the Eastern Cape government, operated an industrial development zone in Port Elizabeth. The industrial development zone was planned to be home to the new deepwater port of Port Elizabeth. Offit Enterprises (Proprietary) Limited owned parcels of land within that zone. After an unsuccessful attempt at expropriation [85], the development corporation continued to threaten Offit with expropriation. However, no formal notice was issued. Offit applied for a declaration that any expropriation of their property with a subsequent transfer to Coega would be unlawful. Jansen J of the Eastern Cape High Court found that the development zone would bring about strategic economic advantages, in particular, the new harbour, which would result in the creation of employment, more value-added production, and a rise in revenue. He concluded that the development zone was both a public purpose and in the public interest because it would benefit the whole population [86]. The Supreme Court of Appeal confirmed the approach of Jansen J [87]. Wallis JA followed pre-constitutional jurisprudence and defined 'public purpose' as any purpose that relates to or benefits the public [88]. He considered that

"[p]roviding industrial development with its concomitant benefits of employment and economic growth is manifestly a public purpose and indeed a central public purpose in South Africa. The establishment of a deep-water port to accommodate changes in world shipping is vitally important in a country whose international trade is largely by sea." [89]. 
He concluded that the expropriation would serve a public purpose and would also be in the public interest [90]. The Offit judgment of the Supreme Court of Appeal shows that economic development generated by a private business project may serve a public purpose, at least within the framework of a greater state-controlled scheme aimed at economic development [91]. In J.R. Harvey v Umhlatuze Municipality and Others, the KwaZulu-Natal High Court approvingly cited the Offit case and specified the outer boundary of 'public purpose' and 'public interest' [92]. The courts would not tolerate an expropriation that would solely serve to benefit a private party or the state's commercial ventures [93].

This analysis demonstrates that the courts refrain from giving a detailed and exhaustive definition of either 'public purpose' or 'public interest'. Instead, they resort to an abstract definition stemming from pre-constitutional jurisprudence. This definition is so broad as to include the indirect economic benefits of private business activities. Expropriations that only serve private interests, however, are not permissible. This raises the question of where the line is between a valid expropriation for private economic development and an unjustifiable expropriation that solely serves a private interest.

\subsection{Who Defines 'Public Purpose'?}

The legislature and the courts can limit the authority's discretion to determine what constitutes a legitimate public purpose for the expropriation of land and property. The more specific the permissible purposes are laid down in legislation, the less scope for maneuvering there will be for the authority [94]. The courts could limit this scope by narrowly defining 'public purpose' and intrusively reviewing the expropriation's purpose.

\subsubsection{The Specificity of Expropriation Legislation}

The South African legislature could easily limit the authority's discretion. Section 25(2) of the Constitution stipulates that property may only be expropriated in terms of a law of general application. This requirement also follows from the principle of legality [95]. As there is no basis for the power to expropriate in common law or customary law [96], an authority's power to expropriate can only be based upon parliamentary statute. Parliament thus automatically plays a role in determining the purpose and circumscribing the authority's discretion. There is even hope that South African law obliges Parliament to set boundaries on the expropriation authority's leeway. The principle of legality requires the law to be sufficiently precise and specific, and Parliament should, therefore, delineate the purpose(s) for which an authority may expropriate property [97].

In reality, the legislature has largely omitted to limit the authority's discretion. Section 2(1) of the Expropriation Act stipulates that the Minister of Public Works can expropriate property for public purposes. This statutory basis is as unspecific as it could possibly be under the Constitution and virtually sets no boundaries to the Minister's discretion in determining the project's purpose. As municipalities carry out many economic development projects, the statutory basis of the municipality's power to expropriate is also relevant. However, none of the empowering provisions in provincial legislation are any more specific [98]. The underlying constitutional or statutory provisions on the powers of municipalities only refer to the functions of the municipalities, which include the abstract purposes of undertaking 'development' or promoting 'economic growth' in the municipality [99].

In light of the Expropriation Act, South African law does not seem to have a culture of detailed expropriation legislation [100]. However, there are over 56 Acts at the national level that authorise expropriations in specific fields [101]. In the field of economic development, there are also notable examples of statutes that directly or indirectly specify the legitimate purpose in more detail. Schedule 1 of the Infrastructure Development Act, for example, specifies for which categories of public infrastructure projects the state may expropriate property. This statute thus specifies the project to a significantly greater extent than the Expropriation Act. Industrial development zones under the Manufacturing Development Act are another example. The Minister of Trade and Industry must inter alia be satisfied that such a zone will facilitate the creation of an industrial complex that will bring about strategic economic advantages, attract strategic investment, increase value-added production, 
and create employment or other socio-economic benefits [102]. An expropriation authority may then expropriate property for an industrial development zone with the determined characteristics on the basis of expropriation legislation [103]. That said, it must be noted neither the Infrastructure Development Act nor any other specific expropriation statute restricts the Expropriation Act's scope of applicability [104]. This means that the competent authorities can make use of its broad authorisation under the Expropriation Act in any case.

Procedurally, the legislature does not require the expropriation authority to conduct a separate impact assessment before it determines the expropriation's purpose. In the expropriation procedure, the expropriation authority is obliged to provide information on the project and the expropriation to adversely affected persons and give them a reasonable opportunity to make representations [105].

The draft 2019 Expropriation Bill does not address the issue of the specificity of purposes. Clause 2(1) would still permit all expropriation authorities to expropriate property for a public purpose or in the public interest. Clause 3 specifically empowers the Minister of Public Works to expropriate property for public purposes or in the public interest. This Bill is so unspecific that it would not limit the powers of the expropriation authorities. With respect to expropriations without compensation, Clause 12(3) of the Bill provides an indicative list of circumstances under which zero compensation may be permissible:

"It may be just and equitable for nil compensation to be paid where land is expropriated in the public interest, having regard to all relevant circumstances, including but not limited to:

(a) Where the land is occupied or used by a labour tenant, as defined in the Land Reform (Labour Tenants) Act, 1996 (Act No. 3 of 1996);

(b) where the land is held for purely speculative purposes;

(c) where the land is owned by a state-owned corporation or other state-owned entity;

(d) where the owner of the land has abandoned the land;

(e) where the market value of the land is equivalent to, or less than, the present value of direct state investment or subsidy in the acquisition and beneficial capital improvement of the land."

This list only partially alleviates the concerns about the State abusing the power to expropriate property without compensation. The list does not specify the purposes for which the State may expropriate property without compensation, but rather the types of land and owners that may be expropriated without compensation. The list itself is not exhaustive and therefore cannot provide sufficient certainty. The listed aspects are not cumulative requirements because any of them may be sufficient to justify zero compensation, and each of them still concerns a large number of cases.

\subsubsection{The Intrusiveness of Judicial Scrutiny}

The role of judicial review in South African law is to control whether the project's purpose falls under 'public purpose' or 'public interest' in terms of the Expropriation Act and the Constitution. In giving a binding interpretation of these terms, the higher courts could theoretically limit the discretion of the expropriation authority. The basis for the judicial review of the expropriation decision in South African law is Section 6(2)(e)(i) of the Promotion of Administrative Justice Act, which allows for a review of whether the expropriation was based upon an authorized reason [106]. The crucial question is whether the courts give their own interpretation of 'public purpose' or 'public interest' and intrusively review the expropriation's purpose or defer to the expropriation authority's determination that the project serves a 'public purpose' or the 'public interest'.

The courts have not explicitly ruled on whether they fully substitute their own interpretation for the authority's interpretation. The fact that the courts have developed their own (broad and abstract) definition of 'public purpose' and that they apply this definition without any reference to a deferential treatment [107], suggests an intrusive judicial review. However, 'public purpose' and 'public interest' 
have proven to be so broad as to include, for instance, the public benefits of a shopping centre in the Bartsch case. With some merit, one may argue that the public purpose/public interest requirement has so little content that an intrusive judicial review of the interpretation of that requirement is barely distinguishable from deference to the authority's determinations [108]. The courts thus do not significantly limit the authority's scope for maneuvering. Combined with unspecific expropriation legislation, this finding entails that it is the competent authority that determines the 'publicness' of the purpose to a large extent.

With respect to expropriation without compensation, the judicial review of the expropriation's purpose will be more intrusive, albeit only indirectly. The expropriation's purpose itself remains subject only to the public purpose/public interest requirement. However, the courts have to scrutinise under Section 25(3) of the Constitution whether zero compensation would be 'just and equitable'. As the expropriation's purpose influences what is 'just and equitable', the courts will have to assess whether the expropriation's purpose justifies the absence of compensation [109].

\subsection{Evaluation of South African Law in the Light of VGGT 16.1}

VGGT 16.1 recommends that states define the concept of public purpose in law to enable effective judicial scrutiny. South African law clearly fails to follow this recommendation. The South African Expropriation Act, which is always applicable, and provincial ordinances that authorise municipalities to expropriate property do not specify the purposes for which the state may expropriate property beyond what is already constitutionally permissible. Provided that the expropriation does not fall foul of the very lenient constitutional public purpose/public interest requirement, South African courts do not engage in substantive scrutiny of the expropriation's purpose. Even indirect economic benefits of private business projects may justify an expropriation. Authorities are thus effectively free to choose the expropriation's purpose. It appears that abstract purposes not only insufficiently limit the authority's discretion, but also create an incentive for courts to defer to the authority's determinations. In this way, the judicial review cannot be considered to be effective.

\section{Conclusions and Suggested Approaches for Legal Reform in South Africa}

Based on the analysis of the 'public purpose' requirements in India and South Africa, striking differences between these two legal systems can be highlighted. While the South African legislature has omitted to specify the legitimate goals of expropriations, the Indian legislature has given a list of purposes that qualify as public purposes. The South African judiciary has also not given a definition of 'public purposes' or the 'public interest' that would significantly reduce the discretion of the expropriation authority to determine the expropriation's goal. In particular, expropriations for economic development are very likely to meet with the courts' blessing in South Africa. By contrast, the Indian Supreme Court has set out to prevent expropriations for private business projects that are only disguised as expropriations for public purposes. The requirement of consent by $80 \%$ of affected persons for such expropriations creates an additional hurdle under Indian law, which is, moreover, easy for the courts to apply. At the same time, additional clarity and limitations are needed in India to prevent states from allowing waivers to key requirements such as SIA and consent that are designed to protect affected landholders.

Measured against Guideline 16.1, South African law fails to meet international standards because its definition of 'public purpose' is insufficiently specific and does not enable the courts to review the expropriation's goal effectively. Indian law, by contrast, meets the international standards entrenched in Guideline 16.1. We, therefore, recommend that the following legal reforms be considered by lawmakers in South Africa (and other countries aiming to reform expropriation procedures).

First, lawmakers should provide a clearly defined list of public purposes to allow for judicial review. If a clearly defined list of permissible purposes is outlined in the law, expropriating authorities are given non-negotiable inventory beyond which they are not permitted to expropriate property 
unless they follow a special procedure. Using this list, judiciaries can effectively monitor and rule on whether the proposed purpose violates the law.

Second, lawmakers should provide a special procedure where the authority wishes to expropriate for another public purpose not listed in the expropriation legislation. This special procedure should, in particular, require the authority to obtain the consent of a certain percentage of all affected parties. This would maximise democratic control and the legitimacy of the expropriation.

Third, the legislature should require the authority to follow a due diligence process. The LARR Act, for instance, requires the authority to conduct an SIA and having their expropriation decision reviewed by an Expert Group. This will not only improve the determination of the expropriation's goal but will also provide a forum for evaluating whether it is feasible for the project to achieve that purpose and whether expropriating the land or property in question is necessary to achieve that purpose. India's LARR Act presents a compelling example of how to establish effective limits on the government's authority to determine what constitutes a 'public purpose'. The decision of whether these requirements in expropriation legislation will depend on the country and context, and will need to be made on a case-by-case basis. Nevertheless, in the absence of any type of due diligence process or scrutiny of the expropriation decision, there may be an increased risk of abuse and misuse of expropriation authority, and consequently additional land conflict, protest, and challenges in court.

As seen in the case of India, the national-level legislation on expropriation should establish clear limits regarding the extent to which states can add, remove, or otherwise alter their state-level laws on expropriation. Otherwise, there is a risk that states will enact legislation on public purpose decision-making which contradicts or undermines national-level legislation that complies with VGGT 16.1.

Author Contributions: The authors jointly designed the methodology. The authors jointly drafted Sections 1, 2 and 5. N.K.T. drafted Section 3. B.H. drafted Section 4 . The authors jointly edited the article and jointly incorporated the reviewers' comments.

Funding: This research received no external funding.

Conflicts of Interest: The authors declare no conflict of interest.

\section{References and Notes}

1. See, for instance, Section 25(2) of the Constitution of the Republic of South Africa, 1996, and its public purpose/public interest requirement. See for expropriation law in Europe: Sluysmans, J.A.M.A.; Verbist, S.; Waring, E.J.L. (Eds.) Expropriation Law in Europe; Kluwer: Deventer, The Netherlands, 2015. See for a comprehensive analysis of the justification of expropriation: Hoops, B. The Legitimate Justification of Expropriation: A Comparative Law and Governance Analysis; Juta: Cape Town, South Africa, 2017. This contribution does not deal with 'Regulatory Takings' or 'Constructive Expropriations', which refer to excessive (and, therefore, compensable) restrictions to Property. Instead, refer to Alterman, R. Takings International: A Comparative Perspective on Land Use Regulations and Compensation Rights; ABA Press: Chicago, IL, USA, 2010.

2. Cotula, L.; Vermeulen, S.; Leonard, R.; Keeley, J. Land Grab or Development Opportunity? Agricultural Investments and International Land Deals in Africa; FAO, International Institute for Environment and Development, International Fund for Agricultural Development: Rome, Italy, 2009; Tagliarino, N.K.; Bununu, Y.A.; Micheal, M.O.; de Maria, M.; Olusanmi, A. Compensation for Expropriated Community Farmland in Nigeria: An In-Depth Analysis of the Laws and Practices Related to Land Expropriation for the Lekki Free Trade Zone in Lagos. Land 2018, 7, 23.

3. Deininger, K.; Selod, H.; Burns, A. The Land Governance Assessment Framework: Identifying and Monitoring Good Practice in the Land Sector; World Bank: Washington, DC, USA, 2012; p. 86.

4. $\quad$ Deininger et al 2012 (fn 3); p. 86. 
5. The World Bank Land Governance Assessment Framework Final Report: Nigeria; World Bank: Washington, DC, USA, 2011; p. 256.

6. Rose, H.; Mugisha, F.; Kananga, A.; Clay, D. Implementation of Rwanda's Expropriation Law and Its Outcomes on the Population. In Proceedings of the Annual World Bank Conference on Land and Poverty, Washington, DC, USA, 14-18 March 2016.

7. Kelo v. City of New London, 545 US 469 (2005).

8. Yardley, J. Farmers Being Moved Aside by China's Real Estate Boom. The New York Times, 8 December 2004. Available online: https://www.nytimes.com/2004/12/08/world/asia/farmers-being-moved-aside-by-chinasreal-estate-boom.html (accessed on 10 October 2019).

9. Yardley 2004 (fn 8).

10. Hoops 2017 (fn 1), pp. 97 et seq and 550 et seq.

11. Goswani, A. Land Acquisition, Rehabilitation and Resettlement: Law, Politics and the Elusive Search for Balance. J. Land Rural Stud. 2016, 4, 3-22. [CrossRef]

12. Van der Walt, A.J. Property Rights, Land Rights, and Environmental Rights. In Rights and Constitutionalism, The New South African Legal Order; van Wyk, D., Dugard, J., de Villiers, B., Davis, M., Eds.; Juta: Cape Town, South Africa, 1994; pp. 455-501.

13. Hoops, B. Expropriation without Compensation: A Yawning Gap in the Justification of Expropriation? S. Afr. Law J. 2019, 136, 261-302.

14. Government Gazette Draft Expropriation Bill, 2019, Clause 12(3); Department of Public Works, No. 1409, 21 December 2018.

15. IDE-Jetro Land Acquisition Issues in Noida District: Background to 'Land Wars' in India. 2011. Available online: http://www.ide.go.jp/library/English/Research/Region/Asia/pdf/1108_sato.pdf (accessed on 10 October 2019).

16. Supreme Court of India, Savitri Dev v. State of Uttar Pradesh, Civil Appeal No. 4506 of 2015.

17. Wahi, N.; Bhatia, A.; Gandhi, D.; Jain, S.; Shukla, P.; Chauhan, U. Land Acquisition in India: A Review of Supreme Court Cases from 1950 to 2016; Centre for Policy Research: New Delhi, India, 2017.

18. Sathe, D. The Political Economy of Land Acquisition in India; Springer: Singapore, 2017.

19. Government of India. The Right to Fair Compensation and Transparency in Land Acquisition, Rehabilitation and Resettlement Act; Government of India: New Delhi, India, 2013.

20. Cernea, M.M. Progress in India: New Legislation to Protect Persons Internally Displaced by Development Projects; Brookings Institution: Washington, DC, USA, 2015.

21. Deininger, K.; Hilhorst, T. Compulsory Land Acquisition in Developing Countries: Shifting Paradigm or Entrenched Legacy? In Eminent Domain: A Comparative Perspective; Kim, I., Lee, H., Somin, I., Eds.; Cambridge University Press: Cambridge, UK, 2017; pp. 118-155.

22. See on methodological aspects: Michaels, R. The Functional Method of Comparative Law. In The Oxford Handbook of Comparative Law; Reimann, M., Zimmermann, R., Eds.; Oxford University Press: Oxford, UK, 2006; pp. 339-382.

23. Hoops 2017 (fn 1); Tagliarino, N.K. Encroaching on Land and Livelihoods: How National Expropriation Laws Measure up against International Standards; World Resources Institute: Washington, DC, USA, 2016; Tagliarino, N.K. National-Level Adoption of International Standards on Expropriation, Compensation, and Resettlement: A Comparative Analysis of Laws Enacted in 50 Countries Across Asia, Africa, and Latin America; Eleven International Publishing: The Hague, The Netherlands, 2019.

24. For more information about the Voluntary Guidelines, see: Hoops, B. Expropriation Procedures in Germany and the Netherlands: Ready for the Voluntary Guidelines on the Responsible Governance of Tenure? Euro. Prop. Law J. 2016, 2016, 236-274; and Verstappen, L.C.A. Multilevel Governance of Property Titles in Land: The Voluntary Guidelines on the Responsible Governance of Tenure of Land, Fisheries and Forests in the Context of National Food Security. In Regulatory Property Rights: The Transforming Notion of Property in Transnational Business Regulation; Godt, C., Ed.; Brill/Nijhoff: Leiden, The Netherlands, 2016; pp. 98-118.

25. Siems, M. Comparative Law; Cambridge University Press: Cambridge, UK, 2014; p. 41.

26. Keith, S.; McAuslan, P.; Knight, R.; Lindsay, J.; Munro-Faure, P.; Palmer, D. Food and Agriculture Organization of the United Nations. Land Tenure Studies 10: Compulsory Acquisition of Land and Compensation; Food and Agriculture Organization (FAO): Rome, Italy, 2008. 
27. Wahi et al. 2017 (fn 17).

28. Government of India, The Land Acquisition Act, 2013, Section 2(1).

29. LARR Act, Sections 9 and 40.

30. Government of India, The Land Acquisition Act, 1894, Section 4(1).

31. LARR Act, Section 2(2)(b)(ii).

32. LARR Act, Section 2(2)(b)(i).

33. LARR Act, Section 41(3).

34. Government of India. The Right to Fair Compensation and Transparency in Land Acquisition, Rehabilitation, and Resettlement (Social Impact Assessment and Consent), Rules, 2014.

35. LARR Act, Section 26(3).

36. The World Bank India Land Governance Assessment National Synthesis Report; World Bank: Washington, DC, USA, 2015.

37. LARR Act, Section 4(4).

38. LARR Act, Section 8.

39. LARR Act, Section 5.

40. LARR Act, Section 7(2).

41. LARR Act, Section 4(2).

42. LARR Act, Section 6.

43. LARR Act, Section 40.

44. LARR Act 2013, Section 11(3).

45. LARR Act, Sections 9 and 41(2).

46. LARR Act, Section 7.

47. LARR Act, Sections 4-5, 7(5), and 8(1).

48. LARR Act, Section 8(2).

49. LARR Act, Section 4.

50. LARR Act, Section 74.

51. LARR Act, Section 2(2).

52. LARR Act, Section 41(9).

53. LARR Act, Section 3.

54. LARR Act, Section 41.

55. Supreme Court of India, Smt. Somavanti and Others vs. The State of Punjab and Others, 1963 AIR 151, 1963 SCR (3) 774.

56. Supreme Court of India. Indrajit C. Parekh of Ahmedabad and Another vs. State of Gujarat and Others, 1975 INDLAW SC 579. Available online: https://indiankanoon.org/doc/745737/ (accessed on 10 October 2019).

57. Supreme Court of India, Sooraram Pratap Reddy vs. District Collector, (2008) 9 S.C.C. 552. Downing, C. Eminent Domain in 21st Century India: What New Delhi Can Learn from New London. J. Int. Law Politics 2013, 46, 207-289, 245.

58. Downing 2013 (fn 63), p. 245.

59. Supreme Court of India, Radhy Shyam(D) Thr. Lrs \& Others vs. State of U.P. \& Others, (2011) 5 SCC 553.

60. Supreme Court of India, Kedar Nath Yadav vs. State of West Bengal \& Others, Civil Appeal No. 8438 of 20. Available online: https://www.escr-net.org/caselaw/2017/kedar-nath-yadav-v-state-west-bengal-otherscivil-appeal-no-8438-2016 (accessed on 10 October 2019).

61. Wahi, N. How Singur Turned the Tide on Land Acquisition in India; The Wire 28 September 2016. Available online: https://thewire.in/68984/singur-turned-tides/?fromNewsdog=1/amp (accessed on 10 October 2019).

62. Mahaprashasta, A.A. Singur Verdict Will Help Mamata Consolidate Her Position in Bengal; The Wire 2 September 2016. Available online: https://staging.thewire.in/politics/will-singur-verdict-consilidate-mamata (accessed on 10 October 2019).

63. Tagliarino 2016 (fn 23); and Hoops 2017 (fn 1).

64. Tagliarino 2019 (fn 23). 
65. Kohli, K.; Gupta, D. Mapping Dilutions in a Central Law: A Comparative analyiss of rules made under the Right to Fair Compensation and Transparency in the Land Acquisition, Rehabilitation and Resettlement (RFCTLARR) Act, 2013. Centre for Policy Research: New Delhi, 2017. Available online: https://www. cprindia.org/news/6456 (accessed on 13 October 2019).

66. Kohli et al. 2017 ( $\mathrm{fn} 74$ ).

67. See an illustrative table of state-enacted waivers to the LARR Act's consent and SIA requirements in the paper of Kohli et al. 2017 (fn 74).

68. Ramesh, J.; Khan, M. Land Acquisition Law: Winking at the States; The Hindu 2 November 2016. Available online: http://www.thehindu.com/opinion/lead/Winking-at-the-States/article16086906.ece (accessed on 10 October 2019).

69. NDTV. On 2013 Land Acquisition Act, Supreme Court's Notice to 5 States; 10 December 2018. Available online: https://www.ndtv.com/india-news/on-2013-land-acquisition-act-supreme-court-notice-to-5-states1960673 (accessed on 10 October 2019).

70. Deodhar, R. Supreme Court to Decide on Land Acquisition Act; Nation 3 April 2019. Available online: https://www.moneylife.in/article/supreme-court-to-decide-on-land-acquisition-act/56764.html (accessed on 10 October 2019).

71. Chandran, R. Court Battles Underline Complexity of India's Myriad Land Laws. Reuters, 9 July 2019. Available online: https://www.reuters.com/article/us-india-landrights-lawmaking/court-battles-underlinecomplexity-of-indias-myriad-land-laws-idUSKCN1U501P (accessed on 10 October 2019).

72. Hoops 2017 (fn 1), pp. 396 et seq.

73. Act 63 of 1975.

74. Eisenberg, A. "Public Purpose" and Expropriation: Some Comparative Insights and the South African Bill of Rights. S. Afr. J. Hum. Rights 1995, 11, 207-221. [CrossRef]

75. Hoops 2017 (fn 1), p. 403.

76. Orange Free State Provincial Division, Fourie v Minister van Lande en ‘n ander, 1970 (4) SA 165 (O) 174 et seq.

77. Appellate Division of the Supreme Court, The Administrator of the Transvaal and Sentrachem Ltd v J van Streepen (Kempton Park) (Proprietary) Limited (640/88) [1990] ZASCA 78, pp. 48 et seq.

78. Slade, B.V. "Public Purpose or Public Interest" and Third Party Transfers. PER 2014, doi.org/10.4314/pelj.v17i1.04; Budlender, G. The Constitutional Protection of Property Rights. In Juta's New Land Law; Budlender, G., Latsky, J., Roux, T., Eds.; Juta: Cape Town, South Africa, 1998; pp. 1-48; Badenhorst, P.J.; Pienaar, J.M.; Mostert, H. Silberberg and Schoeman's The Law of Property, 5th ed.; LexisNexis: Durban, South Africa, 2006; p. 591. et seq.

79. Refer, instead, to the lively discussion in the literature: Van der Walt, A.J. Constitutional Property Law, 3rd ed.; Juta: Cape Town, South Africa, 2011; p. 461. et seq; Southwood, M.D. The Compulsory Acquisition of Rights; Juta: Cape Town, South Africa, 2000; p. 19. Badenhorst; Pienaar; Mostert 2006 (fn 88), p. 567; Slade 2014 (fn 88), pp. 185 et seq; Budlender 1998 (fn 88), pp. 1-49 and 1-55; Mostert, H. The Poverty of Precedent on Public Purpose/Interest: An Analysis of Pre-Constitutional and Post-Apartheid Jurisprudence in South Africa. In Rethinking Expropriation Law I: Public Interest in Expropriation; Hoops, B., Marais, E.J., Mostert, H., Sluysmans, J.A.M.A., Verstappen, L.C.A., Eds.; Boom: The Hague, The Netherlands, 2015; pp. 59-92, 72. et seq; Eisenberg 1995 (fn 84), p. 221; and van Wyk, A.M.A. Planning Law, 2nd ed.; Juta: Cape Town, South Africa, 2012; p. 222.

80. KwaZulu-Natal High Court, eThekwini Municipality v Sotirios Spetsiotis (14688/2009) [2009] ZAKZDHC 51.

81. KwaZulu-Natal High Court, eThekwini Municipality v Sotirios Spetsiotis (14688/2009) [2009] ZAKZDHC 51, para 7.

82. Free State High Court, Bartsch Consult (Pty) Limited v Mayoral Committee of the Maluti-A-Phofung Municipality (4415/2008) [2010] ZAFSHC 11.

83. Free State High Court, Bartsch Consult (Pty) Limited v Mayoral Committee of the Maluti-A-Phofung Municipality (4415/2008) [2010] ZAFSHC 11, para 2.1.

84. Free State High Court, Bartsch Consult (Pty) Limited v Mayoral Committee of the Maluti-A-Phofung Municipality (4415/2008) [2010] ZAFSHC 11, para 5.2.

85. Eastern Cape High Court, Offit Enterprises (Pty) Ltd and Another v Premier, Eastern Cape Government and Others (1764/05) [2006] ZAECHC 6, para 56. 
86. Eastern Cape High Court, Offit Enterprises (Pty) Ltd and Another v Coega Development Corporation (Pty) Ltd and Others (1764/07) [2008] ZAECHC 195, 21 et seq.

87. Supreme Court of Appeal, Offit Enterprises (Pty) Ltd and Another v Coega Development Corporation (Pty) Ltd and Others (9/09) [2010] ZASCA 1.

88. Supreme Court of Appeal, Offit Enterprises (Pty) Ltd and Another v Coega Development Corporation (Pty) Ltd and Others (9/09) [2010] ZASCA 1, para 14.

89. Supreme Court of Appeal, Offit Enterprises (Pty) Ltd and Another v Coega Development Corporation (Pty) Ltd and Others (9/09) [2010] ZASCA 1, para 17.

90. Supreme Court of Appeal, Offit Enterprises (Pty) Ltd and Another v Coega Development Corporation (Pty) Ltd and Others (9/09) [2010] ZASCA 1, para 18.

91. Van der Walt, A.J. Constitutional Property Law. Annual Survey of South African Law 2008, pp. 231-264, p. 260 et seq; Van der Walt, A.J. Constitutional Property Law. Annual Survey of South African Law 2010, pp. 251-294, p. 285.

92. KwaZulu-Natal High Court, J.R. Harvey v Umhlatuze Municipality and Others (4387/08) [2010] ZAKZPHC 86 , para 125 .

93. KwaZulu-Natal High Court, J.R. Harvey v Umhlatuze Municipality and Others (4387/08) [2010] ZAKZPHC 86 , para 124.

94. Southwood 2000 (fn 89), p. 24; Gildenhuys, A.; Grobler, G.L. Expropriation. In Law of South Africa, 2nd ed.; Kanjan, A., Ed.; LexisNexis: Durban, South Africa, 2012, No. 13; Marais, E.J. A Common-Law Presumption, Statutory Interpretation and Section 25(2) of the Constitution-A Tale of Three Fallacies. A Critical Analysis of the Constitutional Court's Arun Judgment. South African Law Journal 2016, pp. 629-663, pp. 655 et seq; Marais, E.J.; Maree, P.J.H. At the Intersection between Expropriation Law and Administrative Law: Two Critical Views on the Constitutional Court's Arun Judgment. PER 2016, 19, pp. 1-54, pp. 9 and 17 et seq.

95. Gildenhuys \& Grobler 2012 (fn 104), No. 13; Marais \& Maree 2016 (fn 104), p. 8.

96. Marais \& Maree 2016 (fn 104), p. 7; Van der Walt 2011 (fn 89), p. 453; Badenhorst, Pienaar; Mostert 2006 (fn 88), p. 565; Gildenhuys, A. Onteieningsreg, 2nd ed.; Buttersworths: Durban, South Africa, 2001; p. 49.

97. Marais \& Maree 2016 (fn 104), pp. 8 et seq; Badenhorst; Pienaar; Mostert 2006 (fn 88), p. 565; Southwood 2000 (fn 89), p. 17; Budlender 1998 (fn 88), pp. 28 et seq; Currie, I.; De Waal, J. Limitation of Rights. In The Bill of Rights Handbook, 6th ed.; Currie, I., De Waal, J., Eds.; Juta: Cape Town, South Africa, 2013; pp. 150-175, 156. et seq; Van der Walt, A.J. Property and Constitution; PULP: Pretoria, South Africa, 2012; p. 28. Woolman, S.; Botha, H. Limitations. In Constitutional Law of South Africa, Vol. 3, 2nd ed.; Woolman, S., Bishop, M., Eds.; Juta: Cape Town, South Africa, 2008; pp. 34-47. et seq, pp. 34-48.

98. Section 79(24)(a)(i) of the Transvaal Local Government Ordinance, No. 17 of 1939; Section 76 of the Local Government Ordinance, No. 8 of 1962 (Free State); and Section 190(1) of the Local Authorities Ordinance, No. 25 of 1974 (Natal).

99. Section 156(5) of the Constitution; Sections 4(2)(g) and 8(1) of the Local Government: Municipal Systems Act, No. 32 of 2000; and Section 83(1) of the Local Government: Municipal Structures Act, No. 117 of 1998; and Section 25(1) of the Spatial Planning and Land Use Management Act (SPLUMA), No. 16 of 2013.

100. Slade 2014 (fn 88), p. 188.

101. Young, C. Expropriations in South Africa: Dramatis Personae of the envisioned Expropriation Law. Eur. Prop. Law J. 2016, 2016, 206-235, 209. [CrossRef] et seq, footnote 24.

102. Regulation 3(a) R1224 (2000).

103. See, for instance, Supreme Court of Appeal, Offit Enterprises (Pty) Ltd and Another v Coega Development Corporation (Pty) Ltd and Others (9/09) [2010] ZASCA 1, para 25.

104. At present, there is no identifiable rule that says that a more specific expropriation statute for economic development-related purposes would render the Expropriation Act inapplicable. See with respect to the Arun judgment in which the Constitutional Court disregarded a specific expropriation statute for the construction of roads: Van der Walt, A.J. Constitutional Property Law. Annual Survey of South African Law 2014, pp. 195-215, p. 212.

105. See Sections 3 and 4 of the Promotion of Administrative Justice Act (PAJA); Hoops 2017 (fn 1), pp. 467 et seq.

106. Act 3 of 2000.

107. Mostert correctly pointed out that a definition of 'public interest' is lacking; see: Mostert 2015 (fn 89 ), p. 88. 
108. Cf. Mostert 2015 (fn 89), p. 87 et seq. See also Smalberger JA's interpretation of a statute permitting an expropriation for a road and for 'any purpose in connection with the construction or maintenance of any road' in the Van Streepen judgment: Appellate Division of the Supreme Court, The Administrator of the Transvaal and Sentrachem Ltd v J van Streepen (Kempton Park) (Proprietary) Limited (640/88) [1990] ZASCA 78, pp. 24 and 31 et seq.

109. Du Plessis, W.J. The Public Purpose Requirement in the Calculation of Just and Equitable Compensation. In Rethinking Expropriation Law I: Public Interest in Expropriation; Hoops, B., Marais, E.J., Mostert, H., Sluysmans, J.A.M.A., Verstappen, L.C.A., Eds.; Boom: The Hague, The Netherlands, 2015; pp. 369-387.

(C) 2019 by the authors. Licensee MDPI, Basel, Switzerland. This article is an open access article distributed under the terms and conditions of the Creative Commons Attribution (CC BY) license (http://creativecommons.org/licenses/by/4.0/). 